\title{
Bibliography
}

Alt, J. E. and D. Dreyer Lassen, 'The political economy of institutions and corruption in American States', Mancur Olson Lecture Series (University of Maryland, April 2002).

Anderson, C. J. and Y. V. Tverdova, 'Corruption, political allegiances, and attitudes toward government in contemporary democracies', American Journal of Political Science, 47:1 (January 2003).

Andvig, J. C. Odd-Helge Fjeldstad, I. Amundsen, K. Tone Sissener and Tina Soreide, Corruption A Review of Contemporary Research (Christian Michelsen Institute, NUPI Report NO 268 NOK 175, 2002).

Arndt, C. and C. Oman, Uses and Abuses of Governance Indicators (OECD Development Centre Studies, 2006).

Bacon, P., Over-Capacity in the Irish Hotel Industry and Required Elements of a Recovery Programme (Irish Hotel Industry, November 2009).

Bardon, J. and D. Keogh, 'Ireland, 1921-84', in J. R. Hill (ed.), A New History of Ireland VII: Ireland 1921-1984 (Oxford University Press, 2003).

Barry, F., 'Institutional capacity and the Celtic Tiger', 8th International Network for Economic Research annual conference (University College Cork, September 2006).

Barry, F., 'Public policymaking and the marketplace for ideas', Transforming Public Services (Trinity College Dublin, 15 September 2009).

Barry, F., Politics and Economic Policymaking in Ireland (Trinity College Dublin, working paper, October 2009).

Bax, Mart, Harpstrings and Confessions: Machine-Style Politics in the Irish Republic (Van Gorcum, 1976).

Bayley, D. H., 'The effects of corruption in a developing nation', Western Political Quarterly, 19:4 (1966).

Belligni, S., Il volto simoniaco del potere (Giappichelli, 1998).

Benoit, K. and M. Marsh, 'For a few Euros more: campaign spending effects in the Irish local elections of 1999', Party Politics, 9:5 (2003).

Benoit K. and M. Marsh, 'The campaign value of incumbency: A new solution to the puzzle of less effective incumbent spending', American Journal of Political Science, 52:4 (2008).

Benoit K. and M. Marsh, 'Incumbent and challenger campaign spending effects 
in proportional electoral systems: the Irish elections of 2002', Political Research Quarterly, 63:1 (2010).

Berg-Schlosser, D. and J. Mitchell (eds), Conditions of Democracy in Europe 1919-1939 (Macmillan/St Martin's, 2000).

Bew, P., Ireland: The Politics of Enmity, 1789-2006 (Oxford University Press, 2007).

Bhagwati, J. N., 'Directly unproductive, profit-seeking activities', Journal of Political Economy, 90:5 (October 1982).

Bielenberg, A., Locke's Distillery: A History (Lilliput, 1993).

Boland, K., The Rise and Decline of Fianna Fáil (Mercier Press, 1982).

Bolton, G. C., The Passing of the Irish Act of Union: A Study in Parliamentary Politics (Oxford University Press, 1966).

Brady, R., Reflections on Tribunals of Inquiry 3 (Bar Review, 1997).

Brunetti, A. and B. Weder, 'A free press is bad news for corruption', Journal of Public Economics, 87:7-8 (2003).

Burgmann, M., 'Constructing legislative codes of conduct lecture in the Department of the Senate', Occasional Lecture Series at Parliament House Australia (23 July 1999).

Burke, T. N., 'Catholicity as revealed in the character of the Irish people delivered in St Gabriel's Church, New York, 4 June 1872', Lectures and Sermons (Haverty, 1873).

Byrne, E., 'Ethics in Public Office Act 1995: public, political \& legislative responses' (degree dissertation, University of Limerick, 2001).

Byrne, E., 'Ireland: Global Corruption Report', in J. Kotalik and D. Rodriquez (eds), Transparency International Global Corruption Report 2006 (Pluto Press, 2007).

Byrne, E., 'Nineteenth and Twentieth Century Political Corruption in Ireland' (PhD dissertation, University of Limerick, 2007).

Byrne E. and J. Devitt, National Integrity Systems, Transparency International Country Study Report on Ireland (Transparency International Ireland, 2009).

Byrne, E., A. K. Arnold and F. Nagano, Building Public Support for Anti-Corruption Efforts Why Anti-Corruption Agencies Need to Communicate and How (World Bank, UNDOCK, 2010).

Catechism of the Catholic Church (Liguori Publications, 1994).

Chari R. S. and H. McMahon, 'Reconsidering the patterns of organised interests in Irish policy making', Irish Political Studies, 18:1 (June 2003).

Chestvale Properties Limited (and) Huddle Investments Limited, Investigation under Section 14(1), Companies Act, 1990: Final Report (Dublin Stationery Office, 1993).

Chubb, B., 'Going about persecuting civil servants: the role of the Irish parliamentary representative', Political Studies, 11:3 (1963).

Clancy, P. and G. Murphy, Outsourcing Government: Public Bodies and Accountability (Task at New Ireland, 2006).

Clifford, M. and Shane Coleman, Bertie Ahern and the Drumcondra Mafia (Hodder Headline, 2009).

Cohen, A. K., 'The study of social disorganization and deviant behaviour', in R. K. Merton, L. B. Broom and L. S. Cottrell, Jr. (eds), Sociology Today (Basic Books, 1959).

Coleman, J., Foundations of Social Theory (Harvard University Press, 1990). 
Collins, N. and C. O'Raghallaigh, 'Political sleaze in the Republic of Ireland', Parliamentary Affairs, 48:4 (1994).

Collins, N. and M. O'Shea, Understanding Corruption in Irish Politics (Cork University Press, 2000).

Collins, S., Breaking the Mould: How the PDs Changed Irish Politics (Gill and Macmillan, 2005).

Committee of Public Accounts, Sub-Committee on Certain Revenue Matters, Examination of the Report of the Comptroller and Auditor General of Investigation into the Administration of Deposit Interest Retention Tax and Related Matters during 1 January 1986 and 1 December 1998 (Dublin Stationery Office, 1999).

Comptroller and Auditor General, Special Report Tribunals of Inquiry (Dublin Government of Ireland, December 2008).

Coogan, T. P., De Valera: Long Fellow, Long Shadow (Hutchinson, 1993).

Cooper, M., Who Really Runs Ireland? The Story of the Elite Who Led Ireland from Bust to Boom ... and Back Again (Penguin Ireland, 2009).

Crawford, H. K., Outside the Glow: Protestants and Irishness in Independent Ireland (University College Dublin Press, 2010).

Creighton, L., The Life and Letters of Mandell Creighton (Longmans, 1904).

Cullen, P., With a Little Help from My Friends: Planning Corruption in Ireland (Gill and Macmillan, 2002).

Curran, M. R., Siúicre Éireann c.p.t., Sugar Distributors (Holdings).Limited, Sugar Distributors Limited (Dublin Stationery Office, 1991).

de Vere White, T., Kevin O'Higgins (Methuen, 1948).

della Porta D. and Y. Mény (eds), Democracy and Corruption in Europe: Social Change in Western Europe (Pinter, 1997).

della Porta, D. and A. Vannucci, 'The "perverse effects" of political corruption', Political Studies, 45 (1997).

della Porta, D. and A. Vannucci, 'Corruption as a normative system', International Conference on Corruption Control in Political Life and the Quality of Democracy: A Comparative Perspective Europe - Latin America (CIES - ISCTE, May 2005).

Devlin Report, Report of Public Services Organisation Review Group 1966-1969 (Dublin Stationery Office, 1969).

Dixit, A., 'On the modes of economic governance', Econometrica, Econometric Society, 1: 2 (2001).

Dobel, P. J., 'The Corruption of a State', American Political Science Review, 72:3 (September 1978).

Dorgan, S., 'How Ireland Became the Celtic Tiger', The Heritage Foundation (23 June 2006), www.heritage.org/research/worldwidefreedom/bg1945.cfm.

Downey, J., All Things New: The 1989 General Election and Its Consequences (Aisling, 1989).

Downey, J., Lenihan: His Life and Loyalties (New Island Books, 1998).

Duignan, S., One Spin on the Merry-Go-Round (Blackwater Press, 1996).

Dunlop, F., Yes, Taoiseach (Penguin, 2004).

Dunphy, R., The Making of Fianna Fáil Power in Ireland (Clarendon Press, 1995). 
Durkheim, E., De la division du travail social: étude sur l'organisation des societies supérieures, trans. G. Simpson (Macmillan, 1933).

Eisenhardt, K. M., 'Building theories from case study research', Academy of Management Review, 14:4 (1989).

Eisenstadt, S. N. and L. Roniger, Patrons, Clients and Friends: Interpersonal Relations and the Structure of Trust in Society (Cambridge University Press, 1984).

Fanning, R., The Irish Department of Finance 1922-58 (Institute of Public Administration, 1978).

Fanning, R., Independent Ireland (Educational Company of Ireland, 1998).

Farrell, B., Seán Lemass (Gill and Macmillan, 1991).

Ferriter, D., The Transformation of Ireland 1900-2000 (Profile Books, 2005).

Finlay, F., Snakes and Ladders (New Island Books, 1998).

FitzGerald, Desmond, Memoirs of Desmond FitzGerald, 1913-1916 (Liberties Press, 2006).

Flood, Mr. Justice Feargus M., Tribunal of Inquiry into Certain Planning Matters and Payments: Second Interim Report (Dublin Stationery Office, 2002).

Foley C.P. and A.G. Barry, Investigation into the affairs of Siúicre Éireann C.p.t. and Related Companies: Final Report (Dublin Stationery Office, 1992).

Friedrich, C.J., 'Political pathology', Political Quarterly, 37 (January-March 1966).

Fukuyama, F., Trust: The Social Virtues and The Creation of Prosperity (Free Press, 1995).

Gallagher, M., 'Stability and turmoil: analysis and results', in M. Gallagher, M. Marsh and P. Mitchell (eds), How Ireland Voted 2002 (Palgrave Macmillan, 2003).

Gallagher, M. and R. Sinnott (eds), How Ireland Voted 1989 (PSAI Press and Centre for the Study of Irish Elections, 1990).

Gallagher, M. and Lee Komito, 'The constituency role of Dáil deputies', in J. Coakley and M. Gallagher (eds), Politics in the Republic of Ireland, 5th ed (Routledge, 2009).

Gambetta, D., The Sicilian Mafia: The Business of Private Protection (Harvard University Press, 1993).

Gardiner, J. A., 'Defining corruption', Corruption and Reform, 7. (1993).

Garvin, T., Nationalist Revolutionaries in Ireland 1858-1928 (Oxford University Press, 1987).

Girvin, B., 'The republicanisation of Irish society: 1932-1948', in J. R. Hill (ed.), A New History of Ireland VII: Ireland 1921-1984 (Oxford University Press, 2003).

Glackin, John A., Chest vale Properties Limited (and) Huddle Investment Limited, Investigation under Section 14(1) Companies Act, 1990 (Dublin Stationery Office, 1993).

GRECO, Third Evaluation Round Evaluation Report on Ireland Transparency of Party Funding (Theme II) (Strasbourg: Council of Europe, September 2009), www.coe.int. Hamilton, Mr. Justice Liam, Report of the Tribunal of Inquiry into the Beef Processing Industry (Dublin Stationery Office, 1994).

Hardiman, N., The Impact of the Crisis on the Irish Political System (Geary Institute: University College Dublin, working paper, November 2009).

Hardiman, N. and C. T. Whelan (eds), Politics and Democratic Values (Gill and Macmillan, 1994). 
Harkness, D., 'Patrick McGilligan: man of commonwealth', Journal of Imperial and Commonwealth History, 5 (1979).

Harling, H., 'Rethinking “old corruption”', Past and Present, 141:1 (May 1995).

Hartley, L. P., The Go-Between (Hamish Hamilton, 1953).

Heaney, S., 'Act of Union', Opened Ground: Pomes 1966-1996 (Faber and Faber, 1998). Heidenheimer, A. J., M. Johnston and V. LeVine (eds), Political Corruption: A Handbook (Transaction 1989).

Hellman, J. S. and D. Kaufmann, Confronting the Challenge of State Capture in Transition Economies (International Monetary Fund, 2001).

Hellman, J. S. and D. Kaufmann, 'The inequality of influence', in J. Kornai and S. RoseAckerman (eds), Building a Trustworthy State in Post-Socialist Transition (Palgrave Macmillan, 2004).

Hellman, J. S., G. Jones and D. Kaufmann, "Seize the State, Seize the Day" State Capture, Corruption, and Influence in Transition (World Bank, 2000).

Henchy, Mr. Justice Seamus, Report of the Tribunal Appointed by the Taoiseach on 4 July 1975 (Allegations against Minister for Local Government). (Purl 4745, July 1975).

Heywood, P., 'Political corruption: problems and perspectives', Political Studies, 45:3 (1997).

Hill, P. B. E., The Japanese Mafia Yakuza, Law, and the State (Oxford University Press, 2003).

Honohan, P., The Irish Banking Crisis Regulatory and Financial Stability Policy 2003-2008: A Report to the Minister for Finance by the Governor of the Central Bank (Government Publications Office, 2010).

Hope K. R. and B. C. Chikulo (eds), Corruption and Development in Africa: Lessons from Country Case Studies (Palgrave, 1999).

Hopkinson, M., 'Civil War and aftermath, 1922-4', in J. R. Hill (ed.), A New History of Ireland VII: Ireland 1921-1984 (Oxford University Press, 2003).

Horgan, J., Seán Lemass: The Enigmatic Patriot (Gill and Macmillan, 1997).

Horgan, J., Irish Media: A Critical History since 1922 (Routledge, 2001).

Horgan, J., Broadcasting and Public Life: RTÉ News and Current Affairs, 1926-1997 (Four Courts Press, 2004).

Huntington, S. P., Political Order in Changing Societies (Yale University Press, 1968).

Hutchcroft, P. D., 'The politics of privilege: rents and corruption in Asia', in A. J. Heidenheimer and M. Johnston (eds), Political Corruption: A Handbook (Transaction: 2002).

Indridason, I. H., 'Coalitions and clientelism: explaining cross-national variation in patterns of coalition formation' (Department of Political Science, University of Iceland, 26 July 2006), www.notendur.hi.is/ihi/CoalitionsClientelism.pdf.

Ingles, T., Moral Monopoly: The Rise and Fall of the Catholic Church in Modern Ireland, 2nd edn (University College Dublin Press, 1998).

Jennings, R., Land Transactions and Prices in the Dublin Area 1974-1978 (An Foras Forbartha, 1980).

Johnston, M., 'Political Corruption: Historical Conflict and the Rise of Standards', in 
L. Diamond and M. F. Platter (eds), The Global Resurgence of Democracy (Johns Hopkins University Press, 1993).

Johnson, M., 'The search for definition: the vitality of politics and the issue of corruption', International Social Science Journal, 48: 149 (1996).

Jones, J. and A. O'Donoghue, In Your Opinion: Political and Social Trends in Ireland through the Eyes of the Electorate (Town House, 2001).

Karvonen, L., Fragmentation and Consensus: Political Organisation and the Interwar Crisis in Europe (Boulder, 1993).

Kaufmann, D., 'Economic corruption: some facts', Eighth International Anti-corruption Conference in Lima (1997), www.8iac.org/papers/kaufinann.html.

Kaufmann, D. and Apart Kraay, Growth Without Governance (World Bank: Policy research working paper 2928, November 2002).

Keena, C., Haughey's Millions: Charlie's Money Trail (Gill and Macmillan, 2001).

Keena, C., The Ansbacher Conspiracy (Gill and Macmillan, 2003).

Kenny, Mr. Justice John, Report (of the) Committee on the Price of Building Land to the Minister for Local Government (Kenny Report). (Dublin Stationery Office, 1973).

Kenny, S. and F. Keane, Irish Politics Now (RTÉ, 1987).

Keogh, D., Twentieth-Century Ireland: Nation and State (Gill and Macmillan, 1994).

Kingston, W., Interrogating Irish policies (Dublin University Press, 2007).

Kinsella, T., Nightwalker and Other Poems (Dolmen Press, 1968).

Kissane, B., Explaining Irish Democracy (University College Dublin Press, 2002).

Kitchell C. K., The Literary and Scientific Repository and Critical Review (Wiley and Halsted, 1821).

Kitchin, R., J. Gleeson, K. Keaveney and C. O'Callaghan, A Haunted Landscape: Housing and Ghost Estates in Post-Celtic Tiger Ireland (National Institute for Regional and Spatial Analysis, working paper 59, July 2010).

Kitschelt H. and S. I. Wilkinson (eds), Patrons Clients, and Policies: Patterns of Democratic Accountability and Political Competition (Cambridge University Press, 2007).

Knack S. and P. Keefer, 'Does social capital have an economic payoff? A cross-country investigation', Quarterly Journal of Economics, 112:4 (November 1997).

Komito, L., 'Development plan rezoning: the political pressures', in J. Blackwell and F. Convery (eds), Promise and Performance: Irish Environmental Policies Analysed (Dublin: Resource and Environmental Policy Centre, University College Dublin, 1983), www.ucd.ie/lkomito.

Komito, L., 'Irish clientelism: a reappraisal', Economic and Social Review, 15:3 (1984).

Krueger, A. O., 'The political economy of the rent seeking society', American Economic Review, 64:3 (June 1974).

Kumlin, S. and Bo Rothstein, 'Making and breaking social capital: the impact of welfare-state institutions', Comparative Political Studies, 38:4 (2005).

Labour Party, One Ireland: Jobs, Reform, Fairness (Labour Party manifesto, 2011).

Lambsdorff, J. G., 'Consequences and causes of corruption: what do we know from a cross-section of countries' (2005). Internet Center for Corruption Research, www. icgg.org/corruption.research_contributions.html. 
LaPalombara, J., 'The structural aspects of corruption', in V. D. Trang (ed.), Corruption and Democracy: Political Institutions, Processes and Corruption in Transition States in East-Central Europe and in the Former Soviet Union (Institute for Constitutional and Legislative Policy, Open Society Institute, 1994).

Larkin, E., The Historical Dimensions of Irish Catholicism (Catholic University of America Press and Four Courts Press, 1984).

Law Reform Commission of Ireland, Consultation Paper On Public Inquiries Including Tribunals of Inquiry: Report 22 (Law Reform Commission, 2003).

Law Reform Commission of Ireland, Public Inquiries Including Tribunals of Inquiry: Report 73 (Law Reform Commission, 2005).

Leahy, P., Showtime: The Inside story of Fianna Fáil in Power (Penguin, 2009).

Lee, J. J., Ireland 1912-1985, Politics and Society (Cambridge University Press, 1989).

Leff, N. H., 'Economic development through bureaucratic corruption', American Behavioural Scientist, 7:3 (November 1964).

Lenihan, A. and Angela Phelan, No Problem: To Mayo and Back (Blackwater Press, 1990).

Lenihan, B., For the Record (Blackwater Press, 1991).

Levi, M., 'A state of trust', in Valerie Braithwaite and M. Levi (eds), Trust and Governance (Russell Sage Foundation, 1998).

Lewis, C. W. and Stuart Gilman, The Ethics Challenge in Public Service: A ProblemSolving Guide, 2nd edn (Jossey-Bass, 2005).

Lowenstein, D. H., 'Legal efforts to define political bribery', in A. J. Heidenheimer, M. Johnston and V. LeVine (eds), Political Corruption: A Handbook (Transaction 1989).

Lyons Tom and Brian Carey, The Fitzpatrick Tapes: The Rise and Fall of One Man, One Bank and One Country (Penguin Ireland, 2011).

MacBride Seán and Caitriona Lawlor, That Day's Struggle: A Memoir 1904-1951 (Curragh Press, 2005).

MacCarthaigh, M., Accountability in Irish Parliamentary Politics (Institute of Public Administration, 2005).

MacCarthaigh, M., Parliamentary Scrutiny of the Administration (Geary Institute: University College Dublin, working paper, November 2009).

Machiavelli, N., The discourses, trans. L. J. Walker (Yale University Press, 1950).

Magill C. W., (ed.), From Dublin to Stormont Castle: The Memoirs of Andrew Philip Magill, 1913-1925 (Cork University Press, 2003).

Mair P. and M. Marsh, 'Political parties in electoral markets in post-war Ireland', in P. Mair, W. Muller and F. Passer (eds), Political Parties and Electoral Change: Party Responses to Electoral Markets (Sage, 2004).

Maltby, A. and B. McKenna, Irish Official Publications, A Guide to Republic of Ireland Papers, with a Breviate of Reports 1922-1972 (Pergamon Press, 1981).

Manning, M., James Dillon: A Biography (Wolfhound Press, 1999).

Mansergh, N., The Irish Free State: Its Government and Politics (Allen and Unwin, 1934).

Martin, W. E., The Mind of Frederick Douglass (University of North Carolina Press, 1984). 
Marsh, M., 'Voting for government coalitions in Ireland under Single Transferable Vote', Electoral studies, 29:3 (2010).

Mauro, P., 'Corruption and growth', Quarterly Journal of Economics, 110:3 (August 1995).

Mays, M., Nation States: The Cultures of Irish Nationalism (Lexington Books, March 2007).

McBride, L., The Greening of Dublin Castle: The Transformation of Bureaucratic and Judicial Personnel in Ireland, 1892-1922 (University of America Press, 1991).

McCarthy, C., 'Corruption in public office in Ireland: policy design as a countermeasure', Economic and Social Research Institute, Quarterly Economic Commentary (2003).

McCracken, Mr. Justice Brian, Report of the Tribunal of Inquiry (Dunnes Payments) (Dublin Stationery Office, 1997).

McCullagh, David, A Makeshift Majority: First Inter-party Government 1948-51 (Institute Public Administration, 1998).

McCullagh, David, The Reluctant Taoiseach: A Biography of John A. Costello (Gill and Macmillan, 2010).

McDonald, Dearhail, Bust (Penguin, 2010).

McDonald, F., Destruction of Dublin (Gill and Macmillan, 1985).

McDonald, F., The Construction of Dublin (Gandon Editions, 2000).

McDonald, F. and K. Sheridan, The Builders (Penguin, 2009).

McDowell, R. B., The Irish Administration, 1808-1914 (London, 1964).

McGraw, Sean, 'Managing change: party competition in the new Ireland' (PhD dissertation, Department of Government: Harvard University, 2009).

McGuire, J. and J. Quinn (eds), Dictionary of Irish Biography: From the Earliest Times to the Year 2002, 4 (Royal Irish Academy, Cambridge University Press, 2009).

McKittrick, D., S. Kelters, B. Feeney and C. Thornton, Lost Lives: The Stories of the Men, Women and Children Who Died as a Result of the Northern Ireland Troubles (Mainstream, 1999).

Meany, Stephen Joseph, Speeches from the Dock (Project Gutenberg eBook, Part I, June 1867), www.gutenberg.org.

Meleady, D., Redmond the Parnellite (Cork University Press, 2008).

Mill, J. S., 'Considerations on representative government', in J. S. Mill, Utilitarianism, Liberty and Representative Government (Dent, Everyman's Library, 1964).

Moody, T. W., R. B. McDowell and C. J. Woods, 'A review of the conduct of administration during the seventh session of Parliament, by an independent Irish Whig, ie Tone, 6 April 1790', The Writings of Theobald Wolfe Tone 1763-98: Volume I: Tone's Career in Ireland to 17 June 1795 (Oxford University Press, 1998).

Moreno, A., 'Corruption and democracy: a cultural assessment', Comparative Sociology, 1 (2002).

Moriarty, Mr. Justice Michael, The Moriarty Tribunal Report. Report of the Tribunal of Inquiry into Payments to Politicians and Related Matters. Parts 1 and 2 (Dublin Stationery Office, 2006, 2011).

Moroff, H. and Verena Blechinger, 'Corruption terms in the world press: how lan- 
guages differ', in A. J. Heidenheimer, M. Johnston and V. LeVine (eds), Political Corruption: A Handbook (Transaction, 1989).

Mulcahy, Roistered, A family Memoir (Aurelia Press, 1999).

Nassmacher, K. H. (ed.), Foundations for Democracy - Approaches to Comparative Political Finance: Essays in Honour of Herbert E. Alexander (Nomos Verlag, 2001).

National Industrial Economics Council, Report of Physical Planning. Report No. 26 (Dublin Stationery Office, 1969).

Noonan, J. T., Bribes (Macmillan 1984).

Nye, J. S., 'Corruption and political development: a cost-benefit analysis', American Political Science Review, 61:2 (June, 1967).

O Broin, L., The Chief Secretary: Augustine Birrell in Ireland (Chatto \& Windus, 1969).

O Broin, L., No Man's Man: A Biographical Memoir of Joseph Brennan (Institute of Public Administration, 1982).

O'Brien, J., The Arms Trial (Gill and Macmillan, 2000).

O’Brien, M., De Valera, Fianna Fáil and the Irish Press (Irish Academic Press, 2001).

O'Brien, M., The Irish Times: A History (Four Courts Press, 2008).

O'Flaherty, L., The Informer (Jonathan Cape, 1925).

O’Halpin, E., 'The Dáil Committee of Public Accounts, 1961-1980', Administration, 32:4 (1985).

O'Halpin, E., “'Ah, they've given us a good bit of stuff...” tribunals and Irish political life at the turn of the century', Irish Political Studies, 15:1 (2000).

O'Halpin, E., 'Politics and the State 1923-32', in J. R. Hill (ed.), A New History of Ireland VII: Ireland 1921-1984 (Oxford University Press, 2003).

O'Leary, C., Irish Elections 1918-1977: Parties, Voters and Proportional Representation (Gill and Macmillan, 1979).

O’Neill T. P. and F. A. Pakenham, Earl of Longford, Éamon de Valera (Arrow Books, 1974).

O’Toole, F., Meanwhile Back at the Ranch: The Politics of Irish Beef (Vintage, 1995).

OECD, Education at a Glance 2008 (OECD, 2008), www.oecd.org/edu.

OECD, Education at a Glance 2010 (OECD, 2010), www.oecd.org/edu.

OECD, Public Management Reviews, Ireland: Towards an Integrated Public Service (OECD, 2008).

Officer, L. H., 'Five ways to compute the relative value of a UK pound amount, 18302006', www.measuringworth.com, 2010.

Oireachtas Select Committee on Building Land, Report of the Joint Committee on Building Land (Dublin: Stationery Office, 5 June 1985).

Paldam, M., 'Corruption and Religion. Adding to the Economic Model' (unpublished manuscript, Aarhus University, Denmark, 1999).

Paltiel, K. Z., 'Campaign finance: Contrasting practices and reforms', in D. Butler, H. R. Penniman and A. Ranney (eds), Democracy at the Polls (American Enterprise Institute, 1981).

Pedersen, M. N., 'The dynamics of European party systems: changing patterns of electoral volatility', European Journal of Political Research, 7:1 (1979).

Philip, M., 'Defining political corruption', Political Studies, 45: 3 (1997). 
Piattoni, S. (ed.), Clientelism, Interests, and Democratic Representation (Cambridge University Press, 2001).

Pinto-Duschinsky, M., 'Political Party Funding', in R. Stapenhurst, N. Johnson, R.

Pelizzo (eds), The Role of Parliament in Curbing Corruption (World Bank, c2006).

Pizzorno, A., Il potere dei giudici (Laterza, 1998).

Plato, The Republic, trans. H. D. P. Lee (Penguin, 1987).

Pollitt, C., C. Talbot, J. Caulfield and A. Smullen, Agencies: How Governments Do Things Through Semi-Autonomous Organizations (Palgrave Macmillan, 2004).

Pope, J., 'Ethics, Accountability and Transparency', in L. Adamolekun, Guy de Lusignan, A. Atomate (eds), Civil Service Reform in Francophone Africa (World Bank, 1996).

Putnam, R., Making Democracy Work: Civic Traditions in Modern Italy (Princeton University Press, 1993).

Putnam, R., Bowling Alone: The Collapse and Revival of American Community (Simon and Schuster, 2000).

Quinn, R., Straight Left: A Journey in Politics (Hodder Headline Ireland, 2005).

Regan, J. M., The Irish Counter-Revolution 1921-1936 Treatyite Politics and Settlement in Independent Ireland (Gill and Macmillan, 1999).

Regling, Klaus and Max Watson, A Preliminary Report on The Sources of Ireland's Banking Crisis (Government Publications Office, 2010).

Report of the Committees of Dáil Éireann 1950-53, Report of the Committee on Procedure and Privileges on the Assault Committed by a Member on another Member in the Oireachtas Restaurant on 31 January 1952 (February 1952).

Report of the Tribunal of Inquiry into Dealings in Great Southern Railway Stocks between the 1st Day of January and the 18th Day of November 1943 (Dublin Stationery Office, 1944).

Reynolds, A., Albert Reynolds: My Autobiography (Transworld Ireland, 2009).

Rhodes, R. A. W., Understanding Governance: Policy Networks, Governance, Reflexivity and Accountability (Open University Press, 1997).

Rose-Ackerman, S., Corruption: A Study in Political Economy (Academic Press, 1978).

Rose-Ackerman, S., 'Democracy and 'grand' corruption', International Social Science Journal, 158:3 (1996).

Rose-Ackerman, S., Corruption and Government (Cambridge University Press, 1999).

Rothstein, Bo., 'Creating political legitimacy: electoral democracy versus quality of government', American Behavioural Scientist, 53:3 (2009).

Rothstein, Bo and Jan Teorell, 'What is quality of government? a theory of impartial government institutions', Governance, 21:2 (2008).

Ryle Dwyer, T., Haughey's Forty Years of Controversy (Mercier Press, 2005).

Sabato, Larry J., Feeding Frenzy: How Attack Journalism Has Transformed American Politics (Lanahan, 1991).

Sacks, P., Donegal Mafia: An Irish Political Machine (Yale University Press 1976).

Sapelli, G., Southern Europe since 1945, Tradition and modernity in Portugal, Spain, Italy, Greece and Turkey (Longman, 1995).

Schmitt, D., The Irony of Irish Democracy: The Impact of Political Culture on Administrative and Democratic Political Development in Ireland (DC Heath, 1973). 
Scott, J. C., 'Corruption, machine politics, and political change', American Political Science Review, 63:4 (December 1969).

Scott, J. C., 'Handling historical comparison cross-nationally', in A. J. Heidenheimer, M. Johnston and V. LeVine (eds), Political Corruption: A Handbook (Transaction 1989).

Senate Select Committee on Ethics, 102-223, 102d Cong., 1st Sess. 11-12, 'Investigation of Senator Alan Cranston, S. Rep.' (1991) www.ethics.house.gov.

Shah, A., 'Tailoring the fight against corruption to country circumstances', in A. Shah (ed.), Performance Accountability and Combating Corruption (World Bank, 2007).

Shang-Jin Wei, Why Is Corruption So Much More Taxing Than Tax? (NBER working paper 6255, 1997).

Sinnott, R., Irish Voters Decide: Voting Behaviour in Elections and Referendums Since 1918 (Manchester University Press, 1995).

Stapenhurst, R., The Media's Role in Curbing Corruption (World Bank Institute: working paper, 2000).

Stevenson, R. L., 'Truth of intercourse', Cornhill Magazine (May 1879).

Steves F. and A. Rousso, Anti-Corruption Programmes in Post-Communist Transition Countries and Changes in the Business Environment, 1999-2002 (European Bank for Reconstruction and Development, working paper 85, 2003).

Stigler, G., 'The theory of economic regulation', Bell Journal of Economics and Management Science, 2:1 (1971).

Suiter, J., 'Chieftains delivering: political determinants of capital spending in Ireland 2001-07' (PhD dissertation, Trinity College Dublin, 2007).

Sullivan, T. D., Recollections of Troubled Times in Irish Politics (Sealy, Bryers \& Walker, M.H. Giull \& Son, 1905).

Swift MacNeil, J. G., What I have Seen and Heard (Little Brown, 1925).

Tanzi, V., Policies, Institutions and the Dark Side of Economics (Edward Elgar, 2000).

Temby, Commissioner Ian, 'Report on Investigation into the Metherall Resignation and Appointment' (Sydney: ICAC, June 1992), quoted in: M. Philp, 'Defining political corruption', Political Studies, 45:3 (1997).

Theobald, R., Corruption, Development, and Underdevelopment (Macmillan, 1990).

Thompson, D. F., 'Mediated corruption: the case of the Keating five', American Political Science Review, 87:2 (1993).

Tobin, F., The Best of Decades: Ireland in the 1960s (Gill and Macmillan, 1984).

Townshend, C., The British Campaign in Ireland 1919-1921 (Oxford, 1975).

Travers, J. Interim Report on Certain Issues of Management and Administration in the Department of Health and Children associated with the Practice of Charges for Persons in Long Stay Health Care in Health Board Institutions and Related Matters (Dublin Stationery Office, Oireachtas Joint Committee on Health and Children, 2005).

Treisman, D., 'The causes of corruption: a cross-national study', Journal of Public Economics, 76:3 (2000).

Twomey, V., The End of Irish Catholicism? (Veritas, 2003).

Uslaner, E. M., 'Trust and corruption', in J. G. Lambsdorff, M. Taube and M. Schramm (eds), The New Institutional Economics of Corruption (Routledge, 2005). 
Vannucci, A., 'The controversial legacy of 'Mani Pulite': a critical analysis of Italian corruption and anti-corruption policies', Bulletin of Italian Politics, 1:2 (2009).

Waldo, W. E., The Mind of Frederick Douglass (University of North Carolina Press, 1984.

Walsh, J., Patrick Hillery: The Authorised Biography (New Island Books, 2008).

Waterbury, J., 'Endemic and planned corruption in a monarchical regime', World Politics, 25:4 (July 1973).

Whitaker, T. K., Interests (Institute of Public Administration, 1983).

Williams, B., B. Hughes and B. Redmond, Managing an Unstable Housing Market (Urban Institute Ireland: University College Dublin, working paper 10/02, 2010).

Williamson, J., and C. Shen, 'Corruption, state strength, and democracy: a crossnational structural analysis', Annual Meeting of the American Sociological Association (Philadelphia, August 2005).

Yin, R. K., Case Study Research, Design and Method, 3rd end (Newbury Park: Sage Publications, 2002).

\section{Dáil debates}

Ahern, Bertie, Dáil Éireann, Supplementary Estimates, 1992: Confidence in Government: Motion. 424. (5 November 1992).

Ahern, Bertie, Dáil Éireann, Written Answers, Tax Amnesty Deadline. 445. (18 October 1994).

Ahern, Bertie, Dáil Éireann, Private Members' Business. Inquiry into Alleged Payments by Dunnes Stores Ltd.: Motion. 472. (10 December 1996).

Ahern, Bertie, Dáil Éireann, Resignation of Member: Statements. 481. (7 October 1997).

Aiken, Frank, Dáil Éireann, Orders of the Day: Local Government Bill, 1931. 39. (17 June 1931).

Boland, Kevin and Gerry L’Estrange, Dáil Éireann, Planning Appeals Bill, 1967: Second Stage (Resumed). 233. (13 March 1968).

Boland, Kevin, Dáil Éireann, Committee on Finance. Vote 26: Local Government (Resumed). 245. (11 March 1970).

Briscoe, Ben, Dáil Éireann, Private Members' Business: Ethics in Government and Public Office Bill, 1991: Second Stage (Resumed). 408. (14 May 1991).

Browne, Noel, Dáil Éireann, Private Members' Business: Office of Taoiseach, Motion. 171. (12 December 1958).

Burke, P. J., Dáil Éireann, Nomination of Member of Government: Motion (Resumed). 246. (7 May 1970).

Burke, Ray, Dáil Éireann, Local Government (Planning and Development) Bill, 1983: Motion. 344. (30 June 1983).

Burke, Ray and Pat O’Mahony, Dáil Éireann, Written Answers: Beef and Sheep Exports to Iraq. 388. (12 April 1989).

Burke, Ray, Dáil Éireann, Personal Statement. 480. (10 September 1997).

Ceann Comhairle, Dáil Éireann, Report of Committee on Procedure and Privileges, Deputy Reprimanded. 129. (5 March 1952). 
Childers, Erskine, Dáil Éireann, Committee on Finance Vote 41: Transport and Power (Resumed). 231. (16 November 1967).

Cole, John and Seán Lemass, Dáil Éireann, Questions: Reorganisation of Great Southern Railways Company. 91. (17 November 1943).

Coogan, Eamonn and Patrick McGilligan, Dáil Éireann, Report of (Ward) Tribunal: Adjournment Debate. 102. (11 July 1946).

Cosgrave, Liam, Dáil Éireann, Financial Resolutions. Statement by Taoiseach and Motion re Tribunal of Inquiry. 283. (3 July 1975).

Costello, John A., Dáil Éireann, Private Deputies' Business: Dáil Restaurant Incident. 129. (31 January 1952).

Dáil Committee on Procedure and Privileges, Draft Report from the Parliamentary Secretary to the Taoiseach. (4 December 1975).

Dardis, John, Seanad Éireann, Tribunal of Inquiry into Beef Processing Industry: Motion. 129. (29 May 1991).

de Valera, Éamon, Dáil Éireann, Proposed Sale of Distillery: Motion for Tribunal 108. (5 November 1947).

de Valera, Éamon, Dáil Éireann, Questions, Oral Answers: Parliamentary Secretaries and Business. 109. (11 December 1947).

de Valera, Major Vivion, Dáil Éireann, Private Deputies' Business: Motion for a Select Committee - Question of Members' Conduct. 101. (15 May 1946).

de Valera, Éamon and Oliver J. Flanagan, Dáil Éireann, Financial Resolutions Report (Resumed) - Proposed Sale of Distillery: Motion for Select Committee (Resumed). 108. (30 October 1947).

de Valera, Éamon, Alfie Byrne, Eamonn Coogan and General Richard Mulcahy Dáil Éireann, Powers and Privileges of the Oireachtas: Motion. 104. (11 March 1947).

de Valera, Éamon, Luke Joseph Duffy, Thomas Foran, Michael Hayes and William Quirke, Seanad Éireann, Allegations Against Parliamentary Secretary: Motion for Tribunal. 31. (5 June 1946).

Dillon, James, Dáil Éireann, Motion for Tribunal. 101. (10 June 1946).

Dillon, James and Seán Lemass, Dáil Éireann, Sheepskin (Control of Export) Bill, 1934: Committee Stage. 51. (22 March 1934).

Dillon, James and Oliver J. Flanagan, Dáil Éireann, Motion for Select Committee. Proposed Sale of Distillery. 108. (29 October 1947).

Figgis, Darrell and Professor William McGinnis, Dáil Éireann, The Prevention of Corrupt Practices at Elections. 1. (20 October 1922).

FitzGerald, Garret, Dáil Éireann, Nomination of Taoiseach. 317. (11 December 1979). Flanagan, Oliver J., Dáil Éireann, Private Deputies' Business. Motion for a Select Committee: Question of Members' Conduct. 101. (15 May 1946).

Flanagan, Oliver J., Dáil Éireann, Order of Business Social Welfare Bill. 532. (31 January 1952).

Haughey, Charles J., Order of Business. 388. (15 March 1989).

Haughey, Charles J., Dáil Éireann, Questions, Oral Answers. Statement by the Minister for Agriculture and Food. 388. (12 April 1989).

Haughey, Charles J., Dáil Éireann, Request to Move Adjournment of Dáil under Standing Order 30. 408. (14 May 1991). 
Howlin, Brendan and Albert Reynolds, Dáil Éireann, Private Members' Business. Ethics in Government and Public Office Bill, 1991: Second Stage. 407. (7 May 1991).

Lemass, Seán and Patrick McGilligan, Dáil Éireann, Committee on Finance Vote 57: Industry and Commerce (Resumed). 57. (19 June 1935).

Lemass, Seán, Dáil Éireann, Wicklow Mining Lease: Appointment of Select Committee. 57. (25 June 1935).

Lemass, Seán, Dáil Éireann, Transport (No. 2) Bill, 1944: Committee (Resumed). 94. (28 September 1944).

Lynch, Jack and Michael Moran, Dáil Éireann, Deputies' Allegations: Censure Motion. 228. (25 February 1976).

MacCarvill, Dr. Patrick, 'Letter addressed to Government dated 22 May 1946', Seanad Éireann (5 June 1946).

MacEntee, Seán, Dáil Éireann, Public Business: Finance Bill, 1935: Second Stage (Resumed). 57. (18 June 1935).

McDowell, Michael and Michael Smith, Dáil Éireann, Report of Tribunal of Inquiry into Beef Processing Industry: Motion (Resumed). 445. (2 September 1994).

McGilligan, Patrick, Dáil Éireann, Twenty-Seventh Report of the Committee of Selection: Mines and Minerals Bill, 1931: Committee. 40. (19 November 1931).

McGilligan, Patrick, Dáil Éireann, Finance Bill, 1935: Second Stage (Resumed). 57. (14 June 1935).

McGilligan, Patrick, Dáil Éireann, Transport Bill, 1944: Second Stage (Resumed). 93. (9 May 1944).

McGilligan, Patrick, Dáil Debates, Committee on Finance: Vote 5, Office of the Minister for Finance. 116. (21 June 1947).

Molloy, Robert, Dáil Éireann, Questions. Oral Answers: Road Safety. 276. (12 December 1974).

Molloy, Robert, Dáil Éireann, Personal Explanation by Minister. 283. (2 July 1975).

Molloy, Robert, Dáil Éireann, Local Government (Planning and Development) Bill, 1973: Committee Stage (Resumed). 282. (25 June 1975).

Mulcahy, General Richard Dáil Éireann, Questions. Oral Answers. Wicklow Mining Lease. 57. (25 June 1935).

Mulcahy, General Richard and William Davin, Dáil Éireann, Transport (No. 2) Bill. Committee (Resumed: Amendment No. 18). 94. (21 September 1944).

Mullen, Michael, Dáil Éireann, Committee on Finance Vote 41: Transport and Power. 230. (9 November 1967).

Noonan, Michael and Dick Spring, Dáil Éireann, Siúicre Éireann and Related Companies Report: Motion. 417. (13 March 1992).

O’Higgins, Kevin, Dáil Éireann, Precedence for Ministerial Business. 1. (27 September 1922).

O’Kennedy, Michael, Dáil Éireann, Meat Industry: Motion. 408. (15 May 1991).

O’Malley, Des, Dáil Éireann, Adjournment Debate, Beef Exports to Iraq. 389. (10 May 1989).

O’Malley, Des, Dáil Éireann, Questions, Oral Answers, Beef Exports to Iraq. 392. (1 November 1989). 
Reynolds, Albert and Pat Rabbitte, Dáil Éireann, Report of Tribunal of Inquiry into Beef Processing Industry. 445 (1 September 1994).

Seanad Éireann, Private Business: Appropriation Bill, 1969 (Certified Money Bill): Second Stage. 67. (2 December 1969).

Spring, Dick, Dáil Éireann, Local Government (Planning and Development) Bill, 1983: Second Stage. 344. (28 June 1983).

Tully, James, Dáil Éireann, Local Government (Roads and Motorways) Bill, 1973 Second Stage. 270. 1974). 270. (7 February 1974).

\section{Newspapers and Periodicals}

\section{Newspapers}

Financial Times

Freeman's Journal

The Guardian

Irish Independent

Irish Press

Irish Times

The Nation

Sunday Business Post

Sunday Independent

Sunday Times

Sunday Tribune

The United Irishman

\section{Periodicals}

Business and Finance

The Economist

Forbes Magazine

Hibernia

Magill Magazine

Nusight

Village Magazine

\section{Archives}

Archbishop John Charles McQuaid Archives, Dublin: Bishops House. Finance 1111 A. Book 4. 1939-46.

National Archives, Dublin, AGO/2002/15/166, Justice: Complaint by Sweetman and O'Higgins addressed to Bar Counsel, 'Bar Counsel letter', 30 December 1947.

National Archives, Dublin, AGO/2002/15/166, Justice: Quirke letter to MacEntee, 25 February 1952.

National Archives, Dublin, S 13866/A, Taoiseach: Allegations against Dr., F. Ward. 
National Archives, Dublin, S 13866/B, Taoiseach: Memorandum to Taoiseach, 19 January 1948.

National Archives, Dublin, S 14153/B, Taoiseach: Locke's Distillery Kilbeggan, Purchase by Aliens 1947.

National Archives, Dublin, S 15153/C, Taoiseach. 1947.

National Archives, Dublin, 2000/6/104, Taoiseach: Local Appointments Commission, 30 November 1966.

National Archives, Dublin, 2001/6/12, Taoiseach: Ministers, Parliamentary Secretaries and Ministers of State, 3 December 1968.

National Archives, Dublin, 99/1/521, Taoiseach: Planning Appeals, 1968.

National Archives, Dublin, 2000/6/650, Taoiseach: Planning Appeals General (Planning Appeals Board), 21 July 1969.

National Archives, Dublin, 2003/16/393, Taoiseach: Planning Appeals General: Planning Appeals Board, 2 September 1971, 18 October; 29 November and 11 December 1972.

National Archives, Dublin, 2005/3/43, President: Price of Building Land Kenny Report, 31 January 1974.

National Archives, Dublin, 2005/7/488, Taoiseach: County councils: corruption; conflict of interest, June 1974.

National Archives, Dublin, 2005/7/520, Taoiseach: Members of Oireachtas and Members of Local Authority. Financial and other interests, June 1974.

National Archives, Dublin, 2005/7/223, Taoiseach: Local Government (Planning and Development) Act, 1976, 18 October 1974.

National Archives, Dublin, S 10553C, Taoiseach: Cabinet Minutes, 2005-06.

National Archives, Dublin, 2008/79/724 408/137/2 Pt IX, Foreign Affairs: ECE Housing Sub Committee - Housing, Building and Planning. 1971-75.

National Library, Dublin, P 189A(6), London. House of Parliament, 1837a. An abridgment of the Evidence given before the Select Committee, Appointed in 1835, to consider the most effectual means of preventing Bribery, Corruption and Intimidation, in the Election of Members to Serve in Parliament. Printed for 'The Reform Association'.

National Library, Dublin, P 1032, London. House of Commons, 1837b. Breviate of the Evidence before the Select Committee of the House of Commons, in 1835, on Bribery, Corruption and Intimidation in the Election of Members to Serve in Parliament. London: J. Ridgway, 1839.

National Library, Dublin, P 1398, J. G. Swift MacNeil, Trinity Law Student's Debating Society: Individuality in its effects on public opinion. An address delivered on the 17th of October, 1875.

National Library, Dublin, LOP 414; LOP 417, East Clare election literature: 'Placehunter v Patriot', 1917.

National Library, Dublin, IR94109 p90, Sinn Féin, The Case of Ireland: 'Sinn Féin Series No. 12'. 1919.

National Library, Dublin, 2A 2571, William Norton, Civil Service Reference Book, 1929.

National Library, Dublin, OPIE PP / 36/4, Interim and Final Report Select Committee 
on the Demise of Certain State Mining Rights, Dáil Éireann Reports of Committees 1932-35. May 1936.

University College Dublin Archives, Dublin, P4/66, P4/617, P4/529, P4/737 7, P4/742 Hugh Kennedy Papers 1920-29.

University College Dublin Archives, Dublin, P7a/95; P7b/23, 24, 25. Richard Mulcahy Papers, 1927.

\section{Law judgements}

Attorney General $v$ The Sole Member of the Tribunal of Inquiry into the Beef Processing Industry [1993] 2 I.R. 250.

Blake v Attorney General [1982] I.R. 117.

Boyhan v Beef Tribunal [1993] 1 I.R. 210, 222.

Haughey $v$ Moriarty [1999] 3 I.R. 1, 57-59.

Redmond $v$ Flood [1999] 3 I.R. 79, 87-88.

97/624/EC: Commission Decision of 14 May 1997 relating to a proceeding pursuant to Article 86 of the EC Treaty. IV/34.621, 35.059/F-3 - Irish Sugar plc

\section{Interviews and correspondence}

Liam Cosgrave, interview (March 2008).

Declan Costello, interview (February 2006).

Eithne FitzGerald, interview (February 2006).

Garret FitzGerald, interview (February 2001).

Stuart Gilman, head of the Global Programme against Corruption and the AntiCorruption Unit of the United Nations Office on Drugs and Crime, interview (October 2007).

Tony Killeen, interview (February 2001).

Joe McAnthony, interview by Bob Quinn. (Clare 2005). DVD of interview courtesy of Joe McAnthony.

Mr. Justice Brian McCracken, interview (February 2001).

Standards in Public Office Commission, interview (July 2006).

Correspondence with Revenue Commissioners, 'Spreadsheet: yield from various Revenue Special Investigations/Initiatives at 31.3.2010' (July 2010).

\section{Websites}

Central Statistics Office, Dublin: www.cso.ie.

Council of Europe, Criminal Law Convention on Corruption, Explanatory Report, Article 12 (2009): www.conventions.coe.int/Treaty/en/Reports/Html/173.htm.

Dáil Committee of Public Accounts, Northern Ireland Relief Expenditure Final Report (13 July 1972): www.193.178.2.84/test/R/1972/en.toc.com.REPORT_13071972_0. html.

Davy Research, Irish Property: Government Finances Exposed to a Correction (2006): www.davydirect.ie/other/pubarticles/irishpropertyoct2006.pdf. 
Department of the Environment, Heritage and Local Government, Housing Statistics (2009): www.environ.ie/en/Publications/StatisticsandRegularPublications/Hous ingStatis.

Enhanced British Parliamentary Papers on Ireland: www.eppi.ac.uk.

EuroBaramoter Polls, Public Opinion Analysis Sector of the European Commission: www.ec.europa.eu/public_opinion/index_en.htm.

Financial Crisis Inquiry Commission, The Financial Crisis Inquiry Report: Final Report of the National Commission on the Causes of the Financial and Economic Crisis in the United States (2011): www.fcic.gov/report.

Moriarty Tribunal, Transcripts (16 February 1999, 22 May 2001, 23 May 2001): www. moriarty-tribunal.ie.

Royal Institute of Chartered Surveyors, European Housing Review 2005/2006 (2007): www.rics.org.

Statement of Mr Justice Michael Moriarty (23 April 2010): www.moriarty-Tribunal.ie. Stewart Macalister, R. A. (ed.), and M. Murphy, Lebor Gabála Érenn: The Book of the Taking of Ireland, Part 6 (2008): www.ucc.ie/celt/LGQS.pdf.

United Nations Office on Drugs and Crime, Fact Sheet 2, Convention Against Corruption: QઐA (2003): www.un.org/webcast/merida/pdfs/03-89373_factsheet2. pdf.

\section{Television}

RTÉ Exit Poll (25 May 2007), www.rte.ie/news/2007/0525/RTEExitPoll2007details. ppt.

RTÉ Mint Productions, Haughey (June 2005).

RTÉ News, 'Obituaries, Charles J. Haughey (1925-2006)', www.rte.ie/news/ob_ cjhaughey.html.

RTÉ News at One (19 December 2006).

RTÉ One, The Big Story (16 August 2009).

RTÉ One, 'Family Fortune: De Valera's Irish Press', Hidden History (November 2004)

RTÉ One, 'Irish Sweepstakes', Hidden History (1 December 2003).

RTÉ One, 'The Pressure Zone', Prime Time Investigates (26 November 2007).

RTÉ Six One News (26 September 2006).

RTÉ Six One News, 'Allowances and expenses, interview with Emmet Stagg' (14 September 2009). 